\title{
Kazuistika I Case report \\ Giant cardiac hydatid cyst mimicking coronary artery disease: imaging assessment. A report of two cases
}

\author{
Fagouri Rim,a, Hala Fennich",a, Loubna Mahfoudib, Fadwa Lachhabb ${ }^{\text {, Ayoub El }}$ \\ Amric, Nawal Doghmia, Mohamed Chertia, Said Moughil ${ }^{b}$
}

a Cardiology B Department of CHU Ibn Sina Rabat, Morocco

${ }^{b}$ Cardiothoracic Surgery B Department of CHU Ibn Sina Rabat, Morocco

' Department of Anaesthesiology of the Cardiothoracic Surgery B, CHU Ibn Sina Rabat, Morocco

* Authors participating equally in this paper: manuscript preparation and literature search.

\section{ARTICLE INFO}

Article history:

Submitted: 23. 10. 2018

Accepted: 21. 1. 2019

Available online: 25. 11. 2019

Klíčová slova:

Echinokoková (hydatidová) cysta

Komplikace

Srdeční

Zobrazování

\section{SOUHRN}

S echinokokovou (hydatidovou) cystou v srdci se Ize setkat ve velmi vzácných, ojedinělých prípadech jako s onemocněním se smrtelnými komplikacemi. Popisujeme dva př́pady pacientů přijatých s bolestí na hrudi a abnormálním EKG záznamem na podkladě obří cystické léze v levé srdeční komoře. I když je echokardiografie velmi citlivý a snadno dostupný diagnostický nástroj, vyšetření jsme dále zpřesnili pomocí různých zobrazovacích metod umožňujících dokonalejší seznámení s morfologickými charakteristikami útvaru i zúžení možností v diferenciální diagnóze. Dosud bylo popsáno málo případů tohoto postižení, kdy byly jako vyšetřovací metody použity transthorakální echokardiografie, magnetická rezonance srdce, výpočetní tomografie se zesíleným kontrastem, koronární výpočetní tomografická angiografie a peroperační jícnová echokardiografie pro vedení chirurgického výkonu.

(c) 2019, ČKS.

\section{ABSTRACT}

Cardiac hydatid cyst is an extremely rare and uncommon localization of the hydatid disease with deadly complications. We report 2 cases admitted for chest pain and abnormal ECG due to a giant cardiac cystic lesion implanted in the left ventricle. Even though echocardiography is a very sensitive and accessible diagnostic

Keywords:

Cardiac

Complications

Hydatid cyst

Imaging tool, we deepened the investigation using all different imaging modalities for a better approach of the morphological features and specificities of each technique and narrowing the differential diagnosis. Only few cases have been fully illustrated through: TTE, cardiac MRI, contrast-enhanced computed tomography, cardiac computed tomography angiography and per-operatory transesophageal echocardiography which guided the surgical procedure.

\section{Introduction}

Cystic echinococcosis; known as hydatid disease; is a human and animal endoparasitic infestation that can reach all organs. Cardiac involvement is a rare condition, responsible of multiple and life-threatening complications. We present here 2 cases of giant cardiac cysts interesting the left ventricle (LV) through all different cardiac imaging modalities.

\section{Case 1}

The first case is a 32-year-old male patient, with a history of lung surgery due to hydatid cysts at the age of 26 and 29. He was admitted to our hospital with complaints of recurrent chest pain increasing on exertion and decreasing by rest since 3 months, which had been aggravated for 1 month. Cardiovascular examination was unremarkable. The electrocardiogram (ECG) showed inverted T waves in $\mathrm{V}_{1}$ to $\mathrm{V}_{6}$ leads. The transthoracic echocardiography (TTE) 

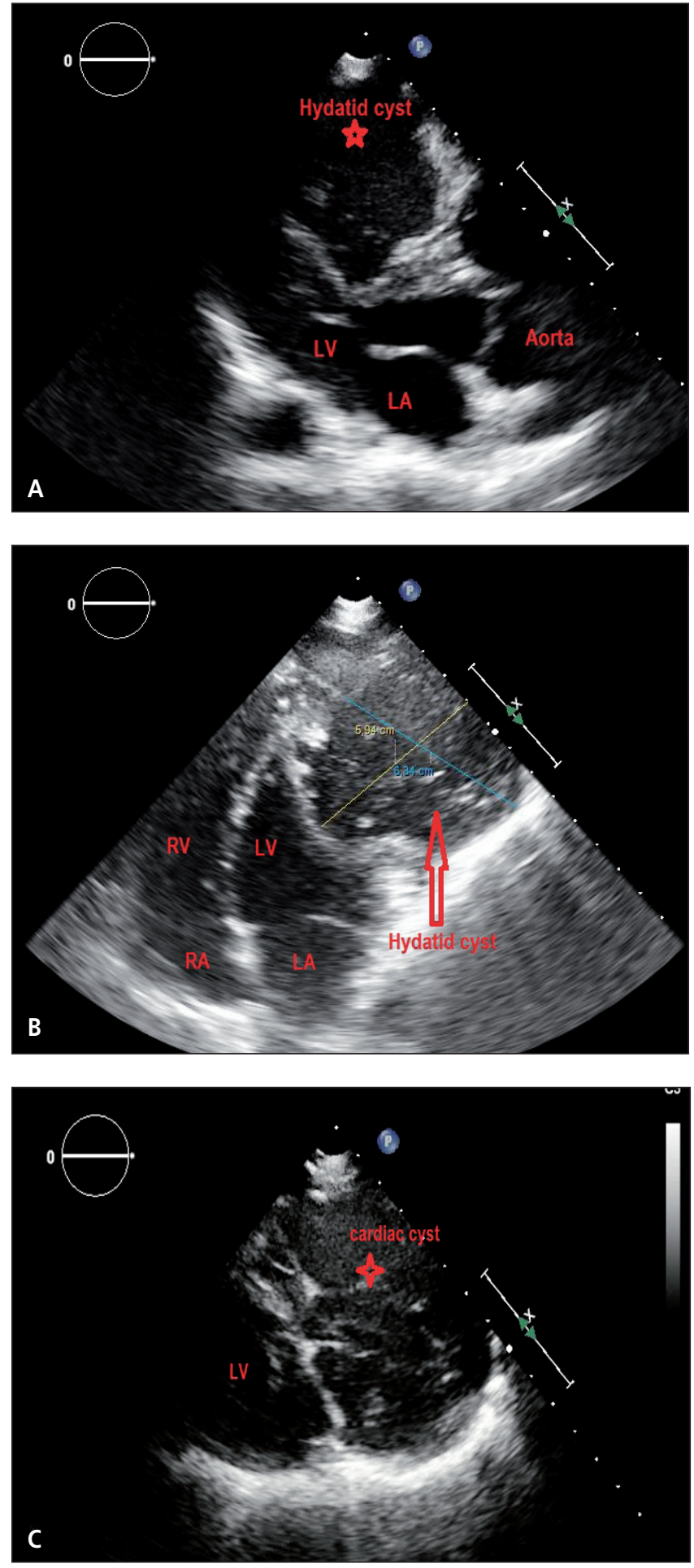

Fig. 1 - Transthoracic echocardiography showing the cardiac hydatid cyst in (A) parasternal long axis view, (B) with a size of $59 \mathrm{~mm} \times$ $63 \mathrm{~mm}$ in four chambers view. (C) This heterogenic cyst is localized at the antero-lateral wall in short axis view.

revealed a heterogenic well circumscribed mass lesion of $59 \mathrm{~mm} \times 63 \mathrm{~mm}$ in diameter originating from the LV wall budging into the cardiac chamber without any LV outflow tract obstruction (Fig. 1). To confirm the diagnosis, cardiac magnetic resonance imaging (MRI) was performed and identified encapsulated mass with a size of $92 \mathrm{~mm} \mathrm{X}$ $78 \mathrm{~mm}$ and extended on $55 \mathrm{~mm}$ (Fig. 2) consistent with
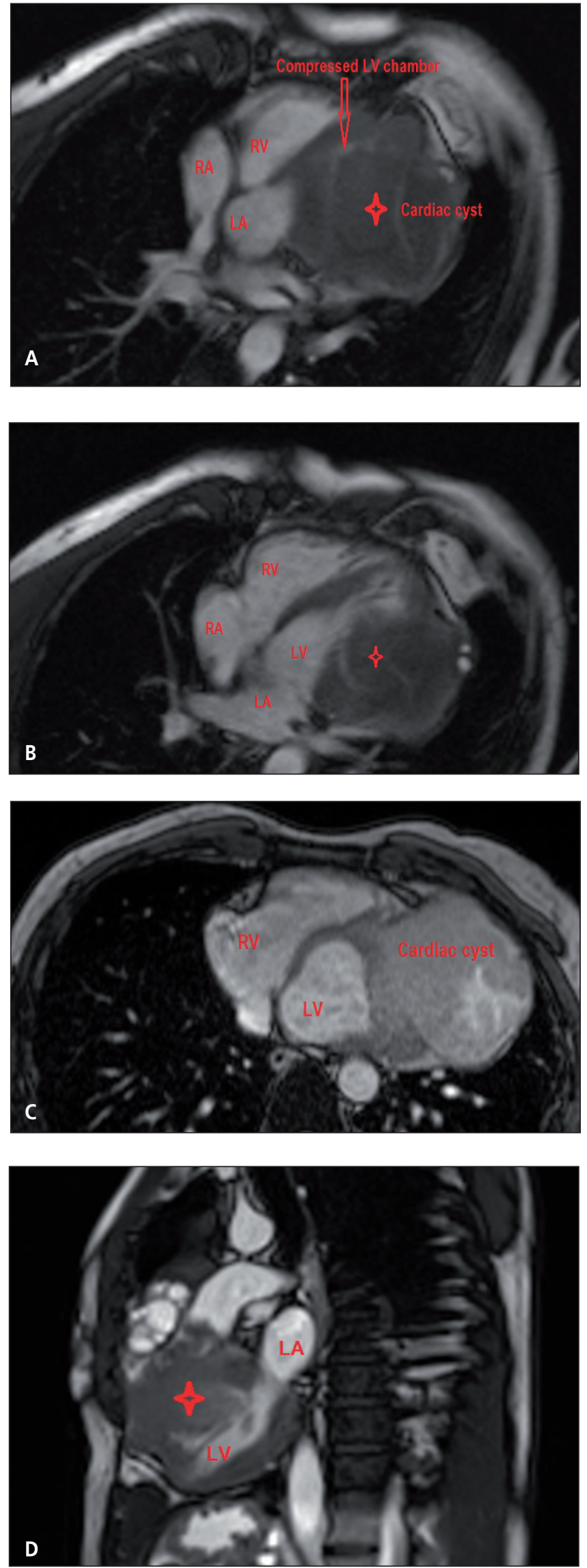

Fig. 2 - Cardiac MRI displaying the huge cyst compressing the LV chamber (A, B, D) containing calcifications (C). 


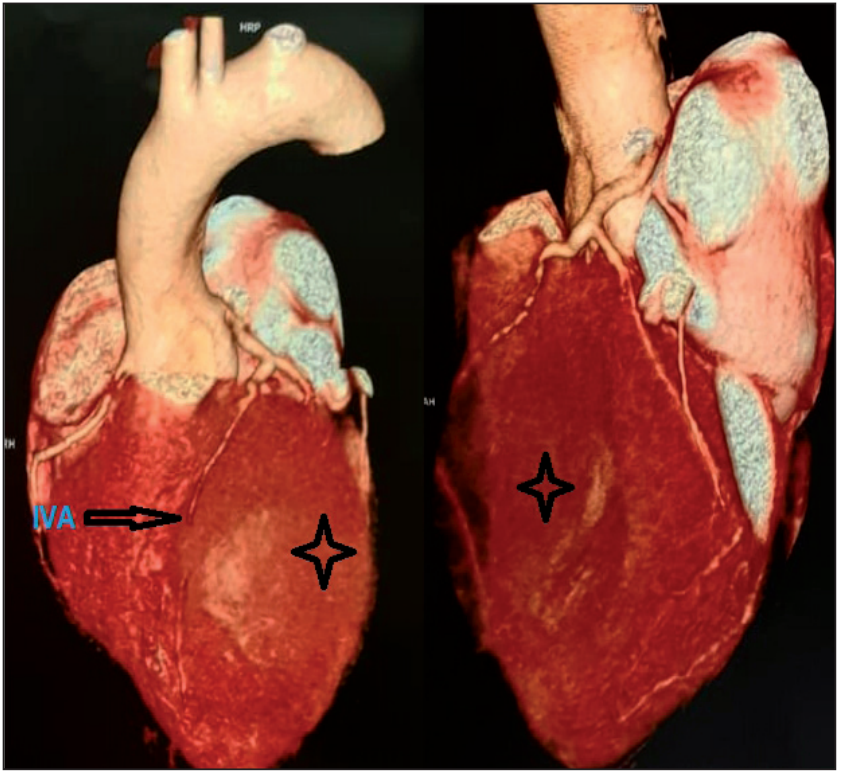

Fig. 3 - 128-slice computed tomography angiography (CCTA) using volume rendering technique showing the anatomic relationship of the cyst with the coronary arteries.

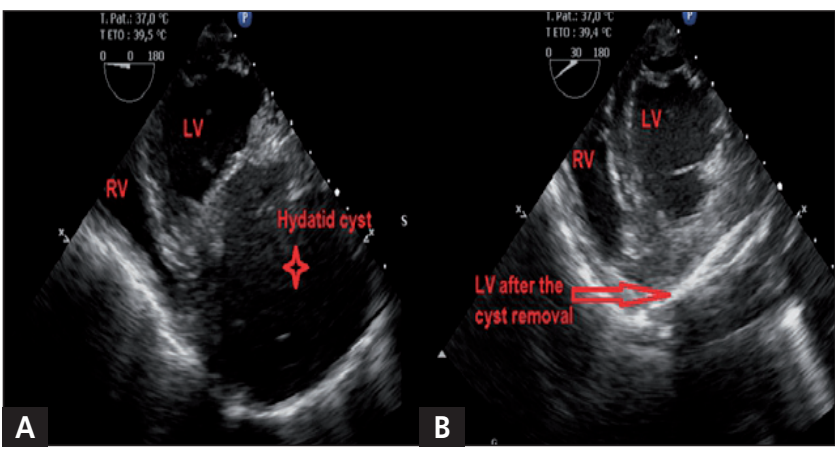

Fig. 4 - Transgastric short axis view in the transesophageal echocardiography demonstrating the LV before (A) and after the cyst resection (B).

hydatid cyst localized at the antero-lateral wall of the LV. The cardiac computed tomography angiography displaying no coronary arteries compression with local thinning of the mid antero-lateral segment (Fig. 3). The patient underwent surgical excision and the per operatory transesophageal echocardiography confirmed the previous findings (Fig. 4). The patient recovered uneventfully and pursued Albendazole therapy.

\section{Case 2}

A 46-year-old female patient with a history of an episode 2 months ago of retrosternal chest pain, radiating to left shoulder associated with profuse sweating, lasting over one hour. Episodes of similar but less severe pain occurred often for the previous 2 weeks. Her ECG showed QS in lateral leads with inverted $T$ waves in $V_{1}$ to $V_{6}$. TTE demonstrated a huge heterogenic mass protruding into the cardiac chambers with a dense texture. The identification of the cardiac localization, the extent and the size

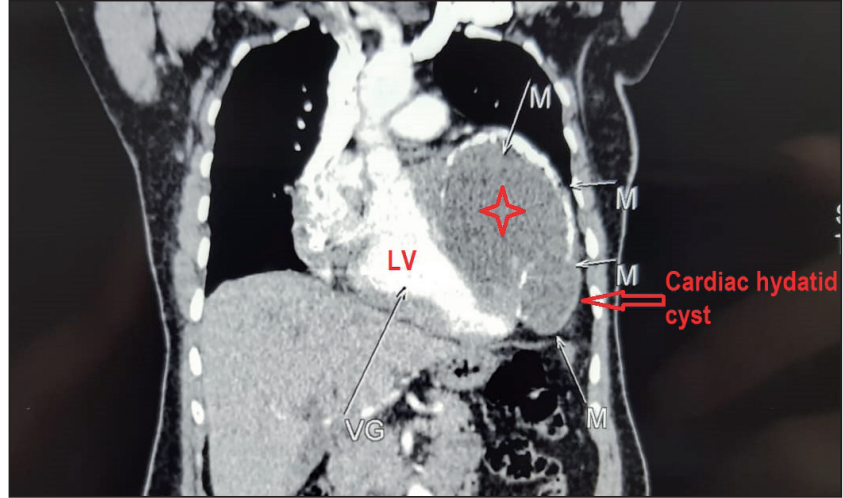

Fig. 5 - Coronal image of contrast-enhanced computed tomography showing non-enhancing multiloculated cardiac cyst in the LV with calcifications.
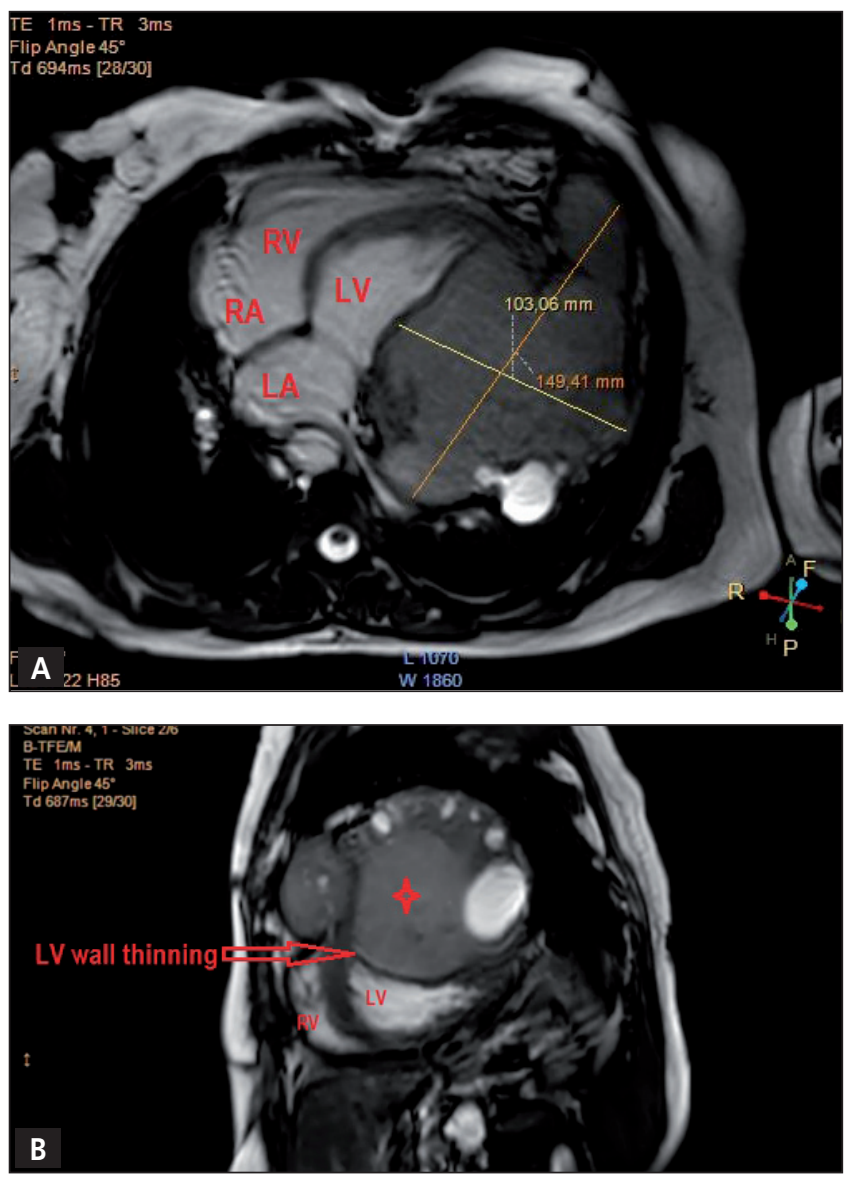

Fig. 6 - The measurement (A) of the cyst in cardiac MRI and the thinning of the LV antero-lateral wall (B).

of this lesion were difficult via TTE. A contrast-enhanced computed tomography (CT) was subsequently performed which showed a huge and multiloculated cardiac cyst with partially calcified walls originating from the LV (Fig. 5). We completed with an MRI that confirmed the previous finding in the antero-lateral wall of the LV with a size of $149 \mathrm{~mm} \times 103 \mathrm{~mm}$ (Fig. 6). The patient refused surgery and any invasive cardiac procedures including coronary angiography. One month after her discharge, she died suddenly and we believe due to the cyst rupture. 


\section{Discussion}

Echinococcosis is a zoonosis parasitic infection that is endemic in certain areas where it remains a major health problem. ${ }^{1}$ This tissue infestation in human being is caused by the larva of Echinococcus granulosus when it is accidentally swallowed. They can reach multiple organs via systemic circulation. The most commonly involved are the liver and the lung in $90 \% .^{2}$ The liver is affected through portal vein and acts as a filter. It can bypass the liver, carried to the lungs via the inferior vena cava. The cardiac involvement is a rare, according to the world health organisation data: $0.03 \%$ to $1.1 \%$ of all hydatid cyst cases. ${ }^{3}$ The coronary circulation is the main pathway by which the larvae reach the heart, but also, the infestation can occur via the pulmonary vein or by direct contact with the hydatid cysts in the liver or the lung. ${ }^{4}$ The left ventricle is more frequently affected (55\%) because it has the richest and the most abundant coronary blood supply and a great myocardial mass for optimal conditions to the development of the parasite. ${ }^{5}$ The clinical presentation is non-specific and may vary according to the localization, the number and the size of the cysts. If the hydatid cyst is not located in a specific and critical anatomic site, it grows slowly between the cardiac fibres and usually remains asymptomatic. Once the cyst is large enough to compress the adjacent structures such as "the coronary micro vessels" disturbing the blood flow; as we believe happened in both cases and since we had no sign of extrinsic compression on the coronary arteries of patient 1 ; it may simulate coronary artery disease (CAD). During the cysts growth and enlarging, they are pushed toward either the epicardium or the endocardium, depending on which is the weaker side of the cardiac wall. The left sided hydatid cysts have usually a subepicardial localization $^{6}$ and then more likely to mimic CAD while compressing the epicardial vessels. Other compressive symptoms have been reported: dyspnea and palpitation due to low cardiac output, ventricular outflow tract obstruction and complete heart block. ${ }^{7}$ The most feared complication is rupture of the cyst into the pericardial cavity or into the cardiac chambers leading to anaphylactic shock and systemic or pulmonary embolism. Although serologic tests are important for the diagnosis, the false-negative are possible. ${ }^{8}$ TTE is the diagnostic modality of choice. Contrast-enhanced $\mathrm{CT}$ and $\mathrm{MRI}$ remain valuable tools and provide specific information about the extent, the anatomic relationships of the cyst and define the morphologic features. They help to exclude differential diagnosis like: ventricular aneurysm and cardiac tumors. Only few reported the importance of Real-time TOE as a fundamental modality to guide the excision for optimal access, and limit damage of the heart structures especially for giant cysts as in case $1 .{ }^{9} \mathrm{~A}$ precise removal through surgical enucleation is the treatment of choice. The operative technique depends on the localization of the cyst, and whether using cardio-pulmonary bypass or operating on beating heart. ${ }^{10}$

\section{Conclusion}

In endemic areas, investigations for systemic cysts must be performed. Even if serologic tests are negative, the imaging modalities give us early diagnosis and valuable information about the lesion and its relation to other structures for successful surgery.

\section{Acknowledgements}

The authors wish to thank the physicians in radiology department of CHU Ibn Sina Rabat for their assistance and intellectual discussion.

\section{Conflict of interest}

The authors declare that there is no conflict of interest.

\section{Ethical statement}

Authors state that the research was performed according to ethical standards.

\section{Appendix A. Supplementary data}

Supplementary data associated with this article can be found in the online version.

\section{References}

1. Charfeddine S, Mallek S, Gueldiche M, et al. A huge cardiac hydatid cyst: An unusual cause of chest pain revealing multivisceral hydatidosis in a young woman. J Saudi Heart Assoc 2015;27:286-291.

2. Tabesh H, Tafti HA, Ameri S. Unusual Presentation of Interventricular Hydatid Cyst: A Case Report. Iran J Public Health 2015;44:130-133.

3. Yaya-Loo HJ, Montalvo GR, Vivas GV. Uncommon Localizations of Echinococcosis: Primary Cerebral and Cardiac Hydatid Cyst. Ann Clin Pathol 2017;5:1106.

4. Tekin AF, Durmaz MS, Dagli M, et al. Left ventricular hydatid cyst mimicking acute coronary syndrome. Radiol Case Rep 2018;13:697-701.

5. Dursun M, Terzibasioglu E, Yilmaz R, et al. Cardiac hydatid disease: CT and MRI findings. AJR Am J Roentgenol 2008;190:226-232.

6. Kaplan M, Demirtas M, Cimen S, Ozler A. Cardiac Hydatid Cysts with Intracavitary Expansion. Ann Thorac Surg 2001;71:15871590.

7. Shah S, Agrawal V, Patel K. Rare case of interventricular septum hydatid cyst causing significant LV outflow tract obstruction. Int J Recent Sci Res 2018;7;69-70.

8. Mohsen T, El Baharry N, Maree T, Akl ES. Cardiac echinococcosis of the interventricular septum in early childhood: report of two cases. J Thorac Cardiovasc Surg 2009;137:e14ee16.

9. Jain PK, Malik V, Divya A, Hote M. Interventricular septal hydatid cyst: Transesophageal echocardiography as a therapeutic tool during bypass. Ann Card Anaesth 2015;18:421-424.

10. Yılmazkaya B, Yondem OZ, Gürkahraman S, et al. Direct approach to hydatid cyst of the interventricular septum. Tex Heart Inst J 2009;36:174-176. 